\title{
ЗАКОНОМЕРНОСТИ СЕМАНТИЧЕСКОЙ ДЕРИВАЦИИ ПРИЛАГАТЕЛЬНЫХ С ИСХОДНЫМ ЗНАЧЕНИЕМ 'СУХОЙ', 'МОКРЫЙ' (НА МАТЕРИАЛЕ РУССКОГО И БЕЛОРУССКОГО ЯЗЫКОВ)
}

Астапкіна К. С. Закономірності семантичної деривації прикметників 3 вихідним значенням 'сухий', ‘мокрий' (на матеріалі російської та білоруської мов).

Стаття присвячена розгляду семантичної деривації в тематичній групі прикметників, які називають ознаки 'сухий - мокрий'. До основних сфер перенесення належать: погода і клімат; характер, поведінка й емоції людини; інтенсивність ознаки; ознаки, що сприймаються іншими органами чуття. Акцентується увага на непродуктивних семантичних перенесеннях.

Ключові слова: тактильна ознака, модель, семантична деривація, похідне значення, чуттєве сприйняття, сема, синестезія, сполучуваність.

Астапкина Е. С. Закономерности семантической деривации прилагательных с исходным значением 'сухой', 'мокрый' (на материале русского и белорусского языков).

Статья посвящена рассмотрению семантической деривации в тематической группе прилагательных, передающих признак 'сухой - мокрый'. Основными сферами переноса являются: погода и климат; характер, поведение и эмоции человека; интенсивность признака; признаки, воспринимаемые другими органами чувств. Отмечаются непродуктивные семантические переносы.

Ключевые слова: тактильный признак, модель, семантическая деривация, производное значение, чувственное восприятие, сема, синестезия, сочетаемость.

Astapkina E. S. The regularities in semantic derivation of the adjectives denoting the property 'dry - wet'.

The article deals with the ways of semantic derivation in the thematic group of adjectives, denoting the property 'dry - wet'. The most productive models are those relating to weather and climate; character, behavior and emotions; intensity of a certain property; qualities perceived by other senses. Nonproductive patterns are given.

Key words: tactile property, model, semantic derivation, derived meaning, perception, seme, synesthesia, compatibility.

Предикатная, признаковая лексика является «основным образным и когнитивным ресурсом языка (в частности, дает обозначения для «невидимых» миров)» [1, с. 215] и «составляет своеобразие семантической организации каждого языка» [8, с. 153]. Одно и то же прилагательное в различных языках или в различных ситуациях может обозначать разные признаки. Здесь «научная картина мира, единая для всех языков, объединяется с «бытовой»- понятийный компонент взаимодействует с 
культурным, что обусловливает разные точки зрения на одно и то же понятие» $[5$, с. $8 ; 6$, с. 23$]$.

Семантическое поле «Восприятие» имеет четкую структуру, отражающую сам процесс физического восприятия, и включает в себя пять микрополей - признаки, воспринимаемые зрением, на слух, на вкус, обонянием и осязательно. В свою очередь каждое микрополе содержит несколько лексико-семантических групп (ЛСГ), имеющих разный объем и разную структуру. Система прилагательных тактильного восприятия в рассматриваемых языках представлена следующими подгруппами: адъективы, описывающие признаки внешнего строения предмета (качество поверхности, признак 'сухой - мокрый') и внутреннего строения предмета (признаки 'твердый - упругий - мягкий'), температурные прилагательные. Объектом данного исследования являются прилагательные, а также адъективированные причастия русского и белорусского языков со значениями 'мокрый', 'сухой', отобранные путем сплошной выборки из толковых словарей [3; 7], взятые в первом (по словарю) значении (лексемы содержат в своей словарной дефиниции следующие идентификаторы: рус. 'не/покрытый, не/пропитанный влагой', 'сухой', 'мокрый', 'сырой', 'влажный'; бел. 'не/насычаны, не/пакрыты вільгаццю', 'мокры', 'вільготны', ‘сухі' - Е. А.).

Выбранные прилагательные в каждом языке образуют два антонимичных блока прилагательных со значениями 'мокрый' (14 лексем русского языка, 31 лексема белорусского языка) и 'сухой' (3 лексемы русского языка, 13 лексем белорусского языка). Лексемы со значениями 'сухой', 'мокрый' образуют антонимичные блоки в едином континууме. Шкала изменения признака выглядит следующим образом: 'очень сухой' - 'сухой' - 'несколько сухой' - 'немного мокрый' - 'мокрый' 'очень мокрый'. Для выражения обоих признаков в рассматриваемых языках используется сходный набор прилагательных, однако лексем с общим значением 'сухой' отобрано гораздо меньше, чем лексем со значением 'мокрый', что может быть связано с исключительной ролью воды, жидкости в жизнедеятельности организма.

Анализ семантических структур прилагательных со значениями 'сухой', 'мокрый', проведенный с целью выявления направлений развития переносных значений, показал, что лексемы, входящие в данную тематическую область, развивают однотипные производные значения. Рассмотрим направления семантических переносов.

Признак 'сухой - мокрый' $\rightarrow$ внутримодальные переносы. Благодаря срединному положению тактильного признака 'сухой - мокрый' (․Е.С. Астапкина, 2015. 
между признаками внешнего и признаками внутреннего строения предмета, в смысловой структуре лексем русского и белорусского языков проявляются «комбинаторные» отношения: а) если в прямом значении есть указание на наличие/ отсутствие влаги на поверхности предмета, то в производном значении лексема будет описывать предмет, не/пропитанный влагой, и наоборот; б) если в прямом значении присутствует указание на тип влаги, например, воду, то в производном значении тип жидкости может меняться (пот, роса). Например, рус. влажный 1 - 'насыщенный, пропитанный влагой': влажный воздух, влажная одежда; влажный 2 - 'покрытый влагой': влажные руки; рус. потный 1 - 'покрытый потом; вспотевший': потный лоб; потный 2 - 'пропитанный потом': потная рубашка.

Сочетание тактильных признаков 'сухой' и 'твердый' находит отражение как в прямом, так и в производном значениях ('лишившийся мягкости, жестковатый, чёрствый (=“сухой и твердый’)'), при этом признак 'твердый' выступает как следствие признака 'сухой': рус. сухой хлеб, сухая рыба; бел. чэрствая глеба; сухая скарынка, сухі батон;

Синестетическое употребление прилагательных, передающих признак 'сухой $\rightarrow$ мокрый'. Диффузность значений рассматриваемых лексем проявляется не только в семантических переносах внутри одной модальности, но и в совмещении признаков разных модальностей. Это позволяет использовать анализируемые прилагательные для описания признаков, воспринимаемых другими органами чувств. Синестетический перенос основывается на сходстве ощущений по линии интенсивности воздействия на органы чувств и эмоциональной оценки.

Перенос тактильного признака 'сухой' происходит на звуковые, вкусовые и зрительные ощущения. Так, при характеристике звука прилагательное тактильного восприятия характеризует громкость (интенсивность звука: рус. суховатый голос, сухой треск, сухой щелчок; бел. сухі металічны лязг, сухое чахканне матора; ), при характеристике зрительно воспринимаемых явлений - яркость (интенсивность цвета / света: бел. сухі бляск), вкусовых свойств - насыщенность (интенсивность вкуса). Лексемы со значением 'сухой' характеризуют звук как 'лишённый звучности, мягкости, сочности', свет - как 'резкий', а вкус - как 'несладкий'. Академические словари русского и белорусского языков не выделяют в отдельное значение способность прилагательного сухой характеризовать вкус, тем не менее, прилагательные активно реализуют данное значение в разговорной речи (например, рус. сухое вино). Сухой также используется для описания фигуры, телосложения человека в значении 'худой' (бел. сухая бабуля). 
Признак 'сухой - мокрый' $\rightarrow$ 'погода, климат'. Признак 'сухой мокрый’ подвергается квантификации и при увеличении количества влаги применяется уже не только для характеристики объектов, способных впитывать влагу (белье, одежда, трава, земля и др.), но и для обозначения относительной влажности воздуха. Модель семантического развития «признак 'сухой - мокрый' $\rightarrow$ 'погода, климат'» является наиболее продуктивной для обоих рассматриваемых языков. Это объясняется тем, что признак 'сухой - мокрый' воспринимается не только тактильно, но и опосредованно, т.е. через воздух. Большинство анализируемых лексем уже в прямом значении описывают влажность воздуха в открытом или закрытом пространстве, погодные условия, климат определенной местности и сочетаются с существительными воздух, ветер, погода, климат, страны, а также с названиями периодов времени (день, ночь, месяи, зима, год). При употреблении с существительными, называющими сравнительно короткие промежутки времени, прилагательные указывают на относительную влажность воздуха. При увеличении промежутка времени (месяц, сезон, год) лексемы в значении 'период с не/большим количеством дождя, осадков’ указывают не на влажность воздуха, а на количество осадков, характерное для этого периода, сезона, года, климата: рус. вечер сыроват, мокрая ночь, сырая погода, сухое лето, сухой климат; бел. волкая ноч, мокрая вясна, сырая пара, сухая зіма, сухая пагода.

Следует отметить, что в данной ситуации имеет место многоступенчатая модель семантической деривации: 'сухой'/‘мокрый' $\rightarrow$ ‘погода в определенный промежуток времени’ $\rightarrow$ ‘климат'. При образовании производных значений данного типа наблюдается синкретизм понятийных сфер ‘погода' и ‘время', ‘погода' и ‘место'. Обозначения времени изначально были связаны с номинациями погоды, так и сейчас время (и место) реализации признака не всегда отделяются от природного явления [4, с. 111].

Признак 'сухой - мокрый' $\rightarrow$ 'интенсивность'. Возможность шкалирования признака обусловила появление производного значения «интенсивности». Лексемы, расширяя прямое значение, передают большее или меньшее количество признака 'сухой - мокрый': рус. мокрый фарш, сухие губы, сухие листья, сухая кожа, сухой хлеб, сухое мясо; бел. падсохлая фарба, сухія асіны, сухія карэнні, пасохлья губы, сухая скарынка.

При обозначении большего или меньшего количества жидкости может подчеркиваться недостаток или избыток влаги, необходимой для жизни, выполнения определенных функций и связанная с этим потеря или нарушение определенных свойств и качеств, что наиболее отчетливо отражено в структуре прилагательных белорусского языка: адмокльля (․ Е. С. Астапкина, 2015. 
расліны, вылмклыя пасевы, сухія асіны, сухія карэнні, сухая рука ('якая не дзейнічае, высахла 3-за якой-небудзь хваробы'), пасохлья губы, cyхая скарынка.

Признак 'сухой - мокрый' $\rightarrow$ 'характер, поведение, эмоции'. Исходя из идеи «отсутствия влаги» как необходимой, осуществляется перенос от тактильно воспринимаемых признаков к характеру, эмоциям, а также проявлениям эмоций субъектом, вернее их отсутствию. При переносе тактильного признака 'сухой' на духовную и эмоциональную сферу человека, базой переноса является именно возможность употребления прилагательных 'твердый', ‘мягкий' с наименованиями продуктов питания, в частности изделиями хлебопекарного производства: черствый хлеб неприятно есть, а с черствым человеком неприятно иметь дело. Общему семантическому компоненту прилагательных со значением 'сухой’ присуща коннотация плохого, неприятного, вызывающего чувство отчужденности, холодности, сдержанности, при этом субъект характеризуется как 'лишённый душевной теплоты, отзывчивости, чуткости; бездушный, чёрствый или намеренно сдержанный, холодный' рус. $c y x$ с коллегами, $c$ дамами, сух в обращении; бел. чэрствы чалавек, чэрствая душа.

Следует отметить, что данные лексемы со значением 'сухой' на основе метафорического значения 'не проявляющий / не выражающий эмоций' развивают метонимическое значения 'свидетельствующий об отсутствии эмоций', 'выражающий бездушие, чёрствость или намеренную сдержанность' и служат для описания таких проявлений эмоционального состояния человека как взгляд, голос, тон: рус. сухой доклад, сухой перечень, сухой язык, сухой тон, сухое обрашение; бел. сухі пераказ, сухія інтсрукиыні, чэрствае слова, чэрствы позірк.

Сухой наиболее активно вступает в сочетание с отвлеченными существительными, обозначающими результат речевой и мыслительной деятельности человека (отчет, доклад, ответ, стиль, язык и др.), характеризует их как лишенные красочности, скупые, лаконичные и, следовательно, выражает отрицательную оценку.

Однако прилагательные со значением 'сухой' могут приобретать и положительную коннотацию в случае указания на отсутствие эмоций и подчеркивая исключительную роль интеллекта, разума при принятии решений, мыслительной деятельности: рус. сухой расчет, бел. сухі разлік. Данное значение указывает на контролируемость эмоций и их подвластность разуму. Лексико-семантические варианты (ЛСВ) прилагательных различных тематических подгрупп ЛСГ прилагательных тактильного восприятия вступают в синонимические отношения. Так, 
например, значение 'основанный на доводах рассудка' развивает и прилагательное холодный, передающее температурный признак, например, рус. холодный расчет; бел. халодная разважлівасцьь.

'Мокрый' $\rightarrow$ 'незавершенность'. Прилагательные русского и белорусского языков (рус. сырой, бел. cырыл) развивают значение 'незавершенный, не готовый'. Так, сырой может характеризовать степень готовности продукта, обработки материала, и сочетаться как с существительными, обозначающими конкретный объект, характеризуя при этом наличие или отсутствие процесса обработки, приготовления, его стадии, так и с существительными, называющими продукты мыслительной и речевой деятельности - в этом случае сырой указывает на незавершенность деятельности, наличие недостатков: рус. полусырое/cblpoе мясо; сырое литье, сырой доклад, сырая работа; бел. сырое мяса, сыры хлеб, сырое ліцицё, сырая паэмка.

Непродуктивные типы семантических переносов. Семантическое развитие прилагательных, передающих признак 'сухой - мокрый', характеризуется регулярностью, однотипностью тематической отнесенности производных значений благодаря наличию одинаковых сем в исходном, прямом значении. Однако существуют и семантические переносы, которые на так частотны в обоих языках.

Наличие влаги, в частности пота, на теле человека или животного может говорить об определенном физиологическом состоянии. Признак 'мокрый' употребляется для указания на активное выделение пота, что может свидетельствовать о физической нагрузке (рус. прибежал домой весь взмыленный (запыхавшийся, вспотевший).

В семантику прилагательных со значением 'сухой' входит отрицание ('не покрытый или не пропитанный влагой'). При использовании лексем с данным значением возникает предположение, что объект может и должен иметь влагу на своей поверхности. На основе этой логики лексемы со значением 'сухой' развивают в своей структуре значение 'постный, без ничего (без приправы, гарнира, начинки' (для характеристики блюд, продуктов питания): бел. сухі хлеб.

Ряд переносных значений прилагательных, обозначающих признак 'сухой', связан с характеристикой свойств процессов, связанных с выделением или отсутствием влаги, например: 1. 'Действующий или производимый при полном отсутствии / наличии влаги, жидкости или небольшом её количестве': рус. сухое прессование, сухой ремонт судна, мокрая уборка помещения; бел. сухі рамонт, сухая атьнкоўка. 2. 'Протекающий при отсутствии влаги, без жидких выделений': рус. сухой (C) Е. С. Астапкина, 2015. 


\section{СТРУКТУРА І СЕМАНТИКА МОВНИХ ОДИНИЦЬ}

кашель, бел. сухі кашаль.

Анализ семантической структуры прилагательных показал, что лексемы со значением 'сухой', 'мокрый' развивают как однотипные производные значения, так и значения, присущие только определенному языку. Наличие групп прилагательных со сходными производящими и производными значениями в рассматриваемых языках, несмотря на единичные типы семантических переносов, позволяет сделать ряд выводов о механизмах осмысления отличных от ситуации тактильного восприятия сфер.

В производных значениях прилагательные со значением 'сухой мокрый’ используются для описания других тактильно воспринимаемых признаков, зрительных, вкусовых и слуховых ощущений, погодных и климатических условий, черт характера, поведения человека, интенсивности проявления признака, физиологических ощущений, оценки, свойств процессов, признака завершенности.

При образовании производных значений наблюдается заметная асимметрия, несмотря на то, что лексемы в каждом языке представляют собой два антонимичных блока. Так, например, прилагательные «сухого» полюса активно используются для характеристики характера, поведения человека, а также таких проявлений эмоционального состояния как тон, голос, взгляд. Данным значениям присуща отрицательная коннотация. Прилагательным «влажного» блока такие производные значения не свойственны. Диффузность проявляется на уровне производных, когда лексико-семантические варианты прилагательных, обозначающих разные признаки, воспринимаемые тактильно, вступают в синонимические отношения (сухой-холодныцй).

\section{Литература}

1. Аспекты семантических исследований / А. А. Уфимцева, Е. С. Кубрякова, Н. Д. Арутюнова и др. ; отв. ред. Н. Д. Арутюнова. - М. : Наука, 1980. - 356 с.

2. Бабаева Е. Э. Мокрый 1.1, влажный 1.1, сырой 1.1 / Е. Э. Бабаева // Новый объяснительный словарь синонимов русского языка / под общ. рук. Ю. Д. Апресяна. Москва ; Вена : Языки славянской культуры, 2004. - С. 538-543.

3. Большой толковый словарь русского языка / [под ред. С. А. Кузнецова]. Санкт-Петербург : Норинт, 1998. - 1536 с.

4. Івашына Н. В. Спалучальнасць прыметнікаў у беларускай і чэшскай мовах / Н. В. Івашына, А. М. Рудэнка // Беларуская мова ў культурнай і моўнай прасторы Славіі : матэрыялы Міжнар. навук. канф. - Мінск : Права і эканоміка, 2009. - С. 111-116.

5. Павлова И. С. Русские прилагательные, обозначающие тепловое восприятие (сопоставит. с болг. и чеш. яз.) : автореф. дис. ... канд. филол. наук / И. С. Павлова. Л., 1978. -15 c. 
6. Рахилина Е. В. Холодно - горячо / Е. В. Рахилина // Научно-техническая информация. Сер. 2. Информационные процессы и системы. - 1999. - № 11. - С. 23-30.

7. Тлумачальны слоўнік беларускай мовы : у 5-и т. / [пад рэд. ак. АН БССР К. К. Атраховіча]. - Мінск : Галоўная рэдакцыя Беларуская савецкай энцыклапеды, 1977-1984.

8. Уфимцева А. А. Лексическое значение : Принцип семиологического описания лексики / А. А. Уфимцева. - М. : Наука, 1986. - 239 с.

Стаття надійшла до редакиії 28.08.2015 p. 